\title{
CHARAKTER PRAWNY UMOWY DAROWIZNY - WYBRANE PROBLEMY
}

\begin{abstract}
Problematyka odwołania darowizny jest skomplikowaną sprawą i nie zawsze ma szansę się powieść. Darowiznę można co prawda odwołać, jednakże wyłącznie z powodu rażącej niewdzięczności obdarowanego wobec darczyńcy oraz gdy stan majątkowy darczyńcy uległ takiemu pogorszeniu, że wykonanie darowizny nie może nastapić bez uszczerbku dla jego własnego utrzymania, odpowiednio do jego usprawiedliwionych potrzeb, albo bez uszczerbku dla ciążących na nim ustawowych obowiązków alimentacyjnych.

Zatem przesłanką konieczną do skutecznego odwołania darowizny jest rażąca niewdzięczność albo pogorszenie się sytuacji majątkowej darczyńcy.

W kodeksie cywilnym jednakże nie wyjaśniono, czym jest „rażąca niewdzięczność”. Odpowiedzi takiej należy szukać w orzecznictwie Sądu Najwyższego, zgodnie z którym „,niewdzięczność” to w szczególności takie zachowania obdarowanego, które są skierowane przeciwko darczyńcy z zamiarem nieprzyjaznym i wrogim. Chodzi tu przede wszystkim o popełnienie przestępstwa przeciwko darczyńcy, np. przeciwko zdrowiu, życiu, czci, mieniu oraz o naruszenie przez obdarowanego obowiązków wynikających ze stosunków osobistych łączących go z darczyńcą - np. odmowa udzielenia pomocy w razie choroby. Nie są traktowane, jako rażąca niewdzięczność drobne czyny - nawet umyślne - ale nie wykraczające poza zwykłe konflikty rodzinne.

Ponadto należy zwrócić uwagę, że nie każde pogorszenie sytuacji majątkowej darczyńcy uzasadnia odwołanie darowizny jeszcze nie wykonanej, gdyż pogorszenie to musi być istotne. Zmiany nieistotne nie dają podstawy do odwołania darowizny. Do odwołania darowizny jeszcze nie wykonanej nie daje również podstaw trudna sytuacja materialna, jeżeli ten stan rzeczy istniał przed zawarciem umowy darowizny

$\mathrm{Na}$ koniec warto też zauważyć, że pomimo niegodnego zachowania obdarowanego darowizny nie można odwołać, jeśli darczyńca obdarowanemu przebaczył. Przebaczenie to może mieć dowolną formę, zarówno ustną jak i pisemną.

Słowa kluczowe: darowizna, odwołanie darowizny, rażąca niewdzięczność.
\end{abstract}

\section{WPROWADZENIE}

Umowa darowizny uregulowana została w Kodeksie Cywilnym ${ }^{2}$ w dziale prawa zobowiązań. „Charakteryzując z punktu widzenia formalnego normy tego działu prawa, można najogólniej powiedzieć, że regulują one stosunki majątkowe typu względnego, a więc prawa podmiotowe (wierzytelności) skuteczne wobec określonych indywidualnie podmiotów”3. Mówiąc ogólniej można powiedzieć, że ,prawo zobowiązań jest tą

\footnotetext{
${ }^{1}$ Mgr Dagmara Florek - Klęsk, Katedra Prawa i Administracji, Wydział Zarządzania, Politechnika Rzeszowska, al. Powstańców Warszawy 6, 35-959 Rzeszów, tel. (0-17) 85244 42, e-mail: dfk@prz.edu.pl

${ }^{2}$ Ustawa z dnia 23 kwietnia 1964r. Kodeks cywilny, tj. Dz.U. 1964, Nr 16, poz. 93 z póź. zm.

${ }^{3}$ Z. Radwański, A. Olejniczak, Zobowiqzania - czesść ogólna, Wyd. C.H. Beck, Warszawa 2006, s. 25 .
} 
częścią prawa cywilnego, która reguluje społeczne formy wymiany dóbr i usług (w najszerszym tego słowa znaczeniu) o wartości majątkowej"4.

\section{POJECIE DAROWIZNY}

Mówiąc o umowie darowizny należy sięgnąć do prawa rzymskiego, stanowiącego podwaliny systemu prawa kontynentalnego, czyli prawa stanowionego.

W okresie poklasycznym w prawie rzymskim uznawano, że darowizna zachodzi we wszystkich tych wypadkach, kiedy pewna czynność prawna:

- pociagga za sobą zwiększenie majątku (wzbogacenie) obdarowanego,

- jednocześnie powoduje zmniejszenie majątku (zubożeniu) darczyńcy,

- jeśli owa czynność wykonana została właśnie w celu przysporzenia korzyści majątkowej obdarowanemu, czyli istniał animus donandi, wola dokonania darowizny,

- jeżeli obdarowany darowiznę przyjął nikogo, bowiem nie można obdarować wbrew jego woli ${ }^{5}$.

Darowizna (donatio) była umową, w której jedna strona (darczyńca) zobowiązywała się do bezpłatnego wzbogacenia drugiej strony kosztem majątku własnego. Darowizna była czynnością prawną dwustronną. Do jej istotnych elementów należała wola obdarowania (animus donandi) po stronie darczyńcy oraz wola przyjęcia darowizny po stronie obdarowanej ${ }^{6}$.

W polskim systemie prawa umowa darowizny, zgodnie z treścią art. $888 \S 1$ k.c. jest umową, w której darczyńca zobowiązuje się do bezpłatnego świadczenia na rzecz obdarowanego kosztem swego majątku.

Umowa stron ma charakter umowy zobowiązującej i jednostronnej w tym znaczeniu, że nie przynosi darczyńcy żadnej odpłaty. Zobowiązanie darczyńcy musi być zamierzone, jako nieodpłatne, musi nastapić na rzecz obdarowanego kosztem majątku darczyńcy i tym samym w majątku osoby obdarowanej powinno nastąpić przysporzenie kosztem majątku darczyńcy.

\section{PRZEDMIOT DAROWIZNY}

Przedmiot darowizny mogą stanowić różne świadczenia, w szczególności:

- $\quad$ przeniesienie wszelkiego rodzaju praw, które poza tym mogą być przedmiotem sprzedaży - zarówno całości, jak i części tych praw, np. części ułamkowej prawa własności rzeczy; prawa, o których mowa mogą dotyczyć rzeczy istniejących lub mających powstać w przyszłości, jak np. pożytki naturalne rzeczy itd.,

- ustanowienie lub zniesienie jakiegoś prawa majątkowego na korzyść obdarowanego,

- $\quad$ zapłata oznaczonej sumy pieniężnej,

- zwolnienie obdarowanego z zobowiązania, jeżeli nie zastrzeżono dla w zamian innego świadczenia, albowiem wówczas zwolnienie takie miałoby już charakter odpłatny; zwolnienie takie może polegać na zwolnieniu z długu ciążącego wobec darczyńcy albo na

\footnotetext{
${ }^{4}$ W. Czachórski, Zobowiazania. Zarys Wyktadu, Wyd. LexisNexis, Warszawa 2009, s. 19.

${ }^{5}$ M. Kuryłowicz, A. Wiliński, Rzymskie prawo prywatne. Zarys wykładu, wyd. Wolters Kluwers Business, Warszawa 2008, s. 267-268.

${ }^{6}$ A. Dębiński, Rzymskie prawo prywatne. Kompendium, Wyd. LexisNexis, Warszawa 2007, s. 309.
} 
zwolnieniu obdarowanego z długu wobec osoby trzeciej, gdy następuje kosztem majątku darczyńcy, np. więc przez zapłatę ${ }^{7}$.

Przedmiotem darowizny mogą być nie tylko rzeczy i prawa majątkowe już będące własnością darczyńcy, lecz także takie, które on dopiero nabędzie. Przedmiot darowizny nie musi też mieć wartości majątkowej, ale jakąkolwiek wartość dla obdarowanego. Nie każde bezpłatne przysporzenia będą darowizną, gdyż art. 889 pkt. 1 i 2 k.c. wyłącza z tego zakresu te świadczenia, które są uregulowane, jako stanowiące przedmiot innych umów, np. bezczynszowa dzierżawa (art. 708 k.c.), użyczenie (art. 710 k.c.), bezprocentowa pożyczka (art. 720 k.c.), jak również te, które są zrzeczeniem się nienabytych jeszcze praw, np. spadku, który się jeszcze nie otworzył, albo uważanego za nienabyty ${ }^{8}$.

Przedmiotem darowizny, zgodnie z orzecznictwem Sądu Najwyższego może być także ekspektatywa ${ }^{9}$ odrębnej własności lokalu, która stanowi podstawę wpisu w księdze wieczystej nabywcy, jako właściciela, niezależnie od chwili złożenia wniosku o dokonanie tego wpisu ${ }^{10}$.

\section{ZAWARCIE UMOWY DAROWIZNY I JEJ SKUTKI PRAWNE}

W celu zapobieżenia pochopnemu wyzbywaniu się składników swego majątku Kodeks Cywilny przewiduje dla oświadczenia darczyńcy formę aktu notarialnego (pod rygorem nieważności). Oświadczenie woli obdarowanego może być złożone w formie dowolnej, również per facta concludentia (wyrażenie zgody, które może nastąpić poprzez pewne czynności dorozumiane, konkludentne - wola osoby dokonywającej czynności prawnej może być wyrażona przez każde zachowanie się tej osoby, które ujawnia jej wolę w sposób dostateczny). Wyraźne osłabienie rygoru formy notarialnej dla oświadczenia darczyńcy sytuuje art. $890 \S 1$ zd. 2 k.c., zgodnie, z którym umowa darowizny zawarta nawet bez zachowania powyższej formy staje się ważna, jeżeli przyrzeczone świadczenie zostanie spełnione ${ }^{11}$.

Pierwszym skutek prawny zawarcia umowy darowizny wynika z jej zobowiązującego charaktery. Darczyńca staje się dłużnikiem o jej wykonanie, natomiast obdarowany wierzycielem. Mimo, że umowa darowizny jest umową zobowiązująca i wymaga wykonania świadczenia ze strony dłużnika, niejednokrotnie świadczenie nastapi już przez samo zawarcie umowy darowizny, lub - z uwagi na stosowne przepisy - pociagnie za sobą uno actu skutek rozporządzający, czyli jeden za wszystkich, wszyscy za jednego ${ }^{12}$.

\footnotetext{
${ }^{7}$ W. Czachórski, Zobowiazania..., s. 549-550.

${ }^{8}$ S. Babiarz, Spadek i darowizna w prawie cywilnym i podatkowym, Wyd. LexisNexis, Warszawa 2008, s. 158.

${ }^{9}$ Ekspektatywa odrębnej własności lokalu jest roszczeniem o ustanowienie przez spółdzielnię odrębnej własności lokalu na rzecz osoby, z którą spółdzielnia zawarła umowę o budowę lokalu (o której mowa w art. 18 ust. 1 Ustawy o spółdzielniach). Roszczenie to powstaje z chwilą zawarcia umowy o budowę lokalu. Ekspektatywa odrębnej własności lokalu podlega też egzekucji, a zatem może w drodze egzekucji przejść na inne osoby. Istnieje możliwość scedowania ekspektatywy wierzytelności na inne podmioty (umowa przyrzeczona zbywalna).

${ }^{10}$ Orzeczenie Sądu Najwyższego z dnia 26 czerwca 2001 r., sygn. I CA 1/01, LexPolonica nr 49117.

${ }^{11}$ T. Filipiak, J. Mojak, M. Nazar, E. Niezbecka, Zarys prawa cywilnego, Wyd. Verba, Lublin 2003, s. 380-381.

${ }^{12}$ W. Czachórski, Zobowiqzania..., s. 549-550.
} 
Kolejne skutki zawarcia umowy darowizny wynikają wprost z treści przepisów Kodeksu Cywilnego, regulujących kwestie wykonania lub niewłaściwego wykonania zobowiązania przez dłużnika. Zgodnie z treścią art. 471 k.c. - dłużnik obowiązany jest do naprawienia szkody wynikłej z niewykonania lub nienależytego wykonania zobowiązania, chyba, że niewykonanie lub nienależyte wykonanie jest następstwem okoliczności, za które dłużnik odpowiedzialności nie ponosi a także zgodnie z dyspozycją art. 516 k.c. zbywca wierzytelności ponosi względem nabywcy odpowiedzialność za to, że wierzytelność mu przysługuje. Za wypłacalność dłużnika w chwili przelewu ponosi odpowiedzialność tylko o tyle, o ile tę odpowiedzialność na siebie przyjął. Należy jednak zauważyć, iż art. 891 i 892 k.c. wprowadzają tutaj odstępstwa ze względu na nieodpłatny charakter tej czynności prawnej, polegające na złagodzeniu rygorów tej odpowiedzialności. Przepisy te łagodzą odpowiedzialność dłużnika na trzech płaszczyznach, mianowicie darczyńca:

- ponosi odpowiedzialność za niewykonanie lub nienależyte wykonanie zobowiązania tylko wówczas, gdy szkodę wyrządzi umyślnie lub na skutek rażącego niedbalstwa (art. $891 \S 1$ k.c.), a tym samym po pierwsze nie ponosi odpowiedzialności za niedochowanie należytej staranności, a po drugie, ciężar dowodu w zakresie rodzaju winy obciąża obdarowanego,

- ponosi odpowiedzialność za opóźnienie w spełnieniu świadczenia, polegającą na możności żądania odsetek przez obdarowanego, od dnia wytoczenia powództwa (art. $891 \S 2$ k.c.),

- odpowiada za wady fizyczne i prawne przedmiotu darowizny w postaci obowiązku naprawienia $\mathrm{z}$ tego tytułu szkody tylko na skutek tego, że wiedząc o wadach, nie zawiadomił obdarowanego o nich i to w czasie właściwym chyba, że obdarowany mógł tę wadę z łatwością wykryć (art. 892 k.c.) ${ }^{13}$.

\section{ODWOLANIE DAROWIZNY}

Jak podaje L. Stecki odwołanie darowizny na charakter jednostronnej czynności prawnej powstałej na skutek zawarcia umowy darowizny. Czynność ta ma na celu uchylenie bądź zniesienie istniejącego stosunku prawnego, jaki nawiązał się pomiędzy obdarowanym

a darczyńcą podczas podpisania umowy darowizny. Składane, zatem przez darczyńce oświadczenie woli na charakter elementu czynności prawnej kształtującej prawo ${ }^{14}$.

Literatura przedmiotu podaje, iż czynność odwołania darowizny w pewnym zakresie przypomina czynność odstąienia od umowy.

Odstapienie od umowy darowizny jak i odwołanie darowizny to takie instytucje, które mają charakter czynności prawnych jednostronnych, które tym samym są czynnościami kształtującymi prawo. Obydwie instytucje zmierzają do uchylenia powstałego stosunku prawnego oraz zniesienia jego następstw. Uprawniony w obu przypadkach dąży do ustanowienia takiego stanu prawnego, jaki istniał przed podpisaniem umowy (status quo ante). Według ustawodawstwa nie można mówić, iż oba te pojęcia są tożsame. Miedzy odwołaniem darowizny a odstąpieniem od umowy zauważamy odmienności przesłanek i

\footnotetext{
${ }^{13}$ S. Babiarz, Spadek..., s. 161-162.

${ }^{14}$ L. Stecki [w:] pod red. J. Rajski, System prawa prywatnego. Prawo zobowiazań - czesść szczegółowa, Tom 7, Wyd. C.H. Beck, Warszawa 2011, s. 358.
} 
głównego celu społecznego. Odwołanie darowizny, zatem posiada pewne cechy oraz elementy kary cywilnej a także zbliża się pojęciowo do zadośćuczynienia za krzywdę doznaną z powodu rażącej niewdzięczności obdarowanego zwłaszcza, jeżeli w jego zachowaniu ujawniają się elementy czynu niedozwolonego ${ }^{15}$.

Bez cienia watpliwości można powiedzieć, że najbardziej przekonujące jest stwierdzenie, iż odwołanie darowizny jest specyficzną rodzajowo, jednostronną czynnością prawną o charakterze kształtującym prawo i mającą na celu rozwiązanie umowy darowizny.

Odwołanie darowizny może nastąić jedynie z przyczyn określonych w Kodeksie Cywilnym. Aby móc skutecznie odwołać darowiznę muszą wystąpić następujące przyczyny:

- darowizna została już wykonana, ale wystąiła rażąca niewdzięczność,

- darowizna została już wykonana, ale darczyńca popadł w niedostatek,

- darowizna nie została jeszcze wykonana,

- zachowanie obdarowanego względem darczyńcy,

- przebaczenie obdarowanemu,

- ubezwłasnowolnienie darczyńcy,

- zasady współżycia społecznego.

\section{FORMA ODWOŁANIA DAROWIZNY}

Zgodnie z treścią art. 900 k.c. odwołanie darowizny następuję przez złożenie obdarowanemu oświadczenia woli na piśmie. Wedle ustawy musi znajdować się w nim oświadczenie o odwołaniu darowizny oraz jego konkretne uzasadnienie. Dokument ten możne również zawierać wpis o żądanie zwrotu przedmiotu darowizny.

W doktrynie jednak występuje pewna różnica zdań dotycząca prawnej formy, w jakiej na występować oświadczenie o odwołaniu darowizny. Część doktryny opowiedziała się za stanowiskiem, ze jest to forma ad solemnitatem. Jest to forma szczególna, której niezachowanie pociaga za sobą nieważność czynności prawnej. Większość jednak twierdzi, iż powinna to być forma ad probationem. Tak z kolei jest to forma, której niezachowanie nie powoduje nieważności czynności prawnej a jedynie ogranicza możliwość skorzystania z niektórych środków dowodowych w razie zaistnienia sporu. W ideologii uważa się, iż pierwszy pogląd jest zbyt skrajny. Forma ad solemnitatem stosowana jest do przepisu art. $73 \S 1$ k.c., jeżeli ustawa przewiduje dla czynności prawnej formę pisemną. Wtedy, gdy czynność prawna dokonana jest bez zachowania zastrzeżonej w regulacji formy staje się nieważna, lecz tylko wtedy, gdy ustawa przewiduje rygor nieważności. Jednak jak wynika $\mathrm{z}$ treści art. 900 k.c. ustawa nie przewiduje występowania takiego rygoru. Adekwatne jest, zatem stwierdzenie, że ad probationem jest forma powszechnie stosowana przy odwołaniach darowizny. W nauce dominuje także sformułowanie, iż nie na potrzeby czynić różnicy, co do formy odwołania darowizny, nawet w przypadku od tego, czy będzie to ruchomość czy tez nieruchomość ${ }^{16}$.

\footnotetext{
${ }^{15}$ M. Warciński, Odwołanie darowizny wykonanej, Instytut Wymiaru Sprawiedliwości, Warszawa 2012, s. 25.

${ }^{16}$ Ibidem, s. 29.
} 


\section{ODWOŁANIE DAROWIZNY NIEWYKONANEJ}

Pojęcie darowizny jeszcze niewykonanej znajduje swe objaśnienie w treści umowy darowizny. Za darowiznę jeszcze niewykonaną należy m.in. uznać sytuację, w której darowane prawo majątkowe wprawdzie przeszło już na obdarowanego (w wyniku umowy o podwójnym skutku obligacyjno - rzeczowym), ale przedmiot darowizny nie został jeszcze wydany przez darczyńcę. Brak wykonania przez darczyńcę jedynie ubocznych obowiązków, których wartość majątkowa jest nieznaczna w porównaniu z wielkością dokonanego przysporzenia, nie może stanowić podstawy do odwołania darowizny wedle koncepcji przyjętej w art. 896 k.c. ${ }^{17}$. Oznacza to, że darowiznę niewykonaną uważa się za taką, w której z punktu widzenia jej treści doszło wprawdzie do ziszczenia się skutku umowy rozporządzająco - zobowiązującej, ale przedmiot świadczenia nie został wydany obdarowanemu albo, gdy w prawdzie doszło do wydania przedmiotu umowy, lecz nie doszło do przejścia własności ${ }^{18}$. Podobne stanowisko zajął Sąd Najwyższy w uchwale z dnia 24 czerwca 2004 r. - złożenie przez obdarowanego deklaracji o przyjęciu w poczet członków spółdzielni mieszkaniowej nie należy do wykonania darowizny (art. 896 k.c.) spółdzielczego własnościowego prawa do lokalu mieszkalnego ${ }^{19}$, a należy tylko spełnienie czynności niezbędnych do rezygnacji z członkostwa ze wskazaniem swego następcy w osobie obdarowanego. Darczyńca może wówczas odwołać skutecznie darowiznę, jeżeli po zawarciu umowy jego stan majątkowy uległ takiej zmianie, że wykonanie darowizny nie mogłoby nastąić:

a) bez spowodowania uszczerbku dla własnego utrzymania darczyńcy odpowiednio do jego usprawiedliwionych potrzeb,

b) albo bez spowodowania uszczerbku na ciążących na nim ustawowych obowiązkach alimentacyjnych (art. 896 k.c. $)^{20}$

Podstawą odwołania przez darczyńcę darowizny niewykonanej jest taka zmiana jego stanu majątkowego, która powoduje, że skutkiem wykonania darowizny byłby uszczerbek dla usprawiedliwionych kosztów jego utrzymania albo ustawowych obowiązków darczyńcy. Powołany przepis odnosi się, zatem do sytuacji wyjątkowych, bowiem powołanie się przez darczyńcę na ciężką sytuację majątkową nie może doprowadzić do skutecznego odwołania darowizny, jeżeli sytuacja taka wystapiła przed zawarciem umowy darowizny albo została spowodowana ta umowa, będącą nierozważnym krokiem zobowiązującego się do świadczenia ${ }^{21}$

Takiej interpretacji omawianego przepisu, Sąd Najwyższy dał wyraz w orzeczeniu z dnia 27 listopada 1998 r. Ustalając, czy powód domagający się renty od obdarowanego (art. 897 k.c.) znajduje się $\mathrm{w}$ niedostatku, sąd bierze pod rozwagę również środki utrzymania czerpane $\mathrm{w}$ ramach wspólnoty rodzinnej powstałej w wyniku zawarcia

\footnotetext{
${ }^{17}$ W. Czachórski, Zobowiqzania..., s. 552.

${ }^{18}$ S. Babiarz, Spadek..., s.162.

${ }^{19}$ Uchwała Sądu Najwyższego z dnia 24 czerwca 2004 r. sygn. III CZP 30/04, LexPolonica nr 108156.

${ }^{20}$ W. Czachórski, Zobowiazania..., s. 552-553.

${ }^{21}$ S. Dmowski [w:] pod red. G. Bieniek, Komentarz do kodeksu cywilnego. Księga Trzecia. Zobowiazania, Tom 2, Wyd. LexisNexis, Warszawa 2007, s. 794.
} 
związku małżeńskiego wyznaniowego ${ }^{22}$. Jest przy tym niesporne to, że wskazane przesłanki muszą być rozumiane tak, jak rozumie się je w prawie rodzinnym, skoro ustawodawca wykorzystuje te same pojęcia (art.128 - 135 Kodeksu rodzinnego i opiekuńczego $\left.^{23}\right)$. Zmiana tego stanu powinna nastapić dopiero po zawarciu umowy, ale przed jej wykonaniem, co z kolei oznacza, że nie jest nią sam fakt zawarcia umowy, bo on w zasadzie sam przez się faktycznie takiej zmiany nie powoduje, np. zawarcie tylko umowy darowizny przenoszącej własność nieruchomości, ale bez jej wydania ${ }^{24}$.

W prawie cywilnym obowiązuje wiele zasad, mających swoje źródło w rzymskim prawie prywatnym. Ogólnie panująca zasada pacta sunt servanda, mówi jednoznacznie, że umów należy dotrzymywać. Jednak na podstawie treści przepisu art. 897 k.c. można wywodzić inną zasadę, tj. rebus sic stantibus, która pozwala stronom umowy na sądową zmianę pierwotnego zobowiązania wynikającego $\mathrm{z}$ tej umowy, w przypadku nadzwyczajnej zmiany stosunków społecznych. Aby zastosować klauzulę rebus sic stantibus muszą zaistnieć wszystkie następujące przesłanki:

- nastąpi nadzwyczajna zmiana stosunków,

- zmiana ta powoduje nadmierne trudności w spełnieniu świadczenia albo grozi jednej ze stron rażącą stratą,

- strony nie przewidywały wpływu nadzwyczajnej zmiany stosunków na zobowiązanie, przy czym istotny jest brak przewidzenia nie tyle samej zmiany stosunków, co jej wpływu na zobowiązanie ${ }^{25}$.

Przy takim rozumieniu sytuacji, w której sprawy przybrały inny obrót do głosu dochodzi również metoda wnioskowania ,z większego na mniejsze”, zatem skoro komuś można więcej tym bardziej można mu mniej. Na podstawie wnioskowania a maiori ad minus można uznać za legalne odwołanie tylko części darowizny. Z punktu widzenia art. 896 k.c. bez znaczenia dla dopuszczalności odwołania darowizny jest to, jakie przyczyny spowodowały zmianę stanu majątkowego u darczyńcy, a więc czy były one przez niego zawinione, czy też nie, $\mathrm{z}$ wyjątkiem umyślnych działań skierowanych w celu doprowadzenia do możności odwołania darowizny, gdyż byłoby to zaprzeczeniem idei tej umowy. Możliwe jest w związku z tym także częściowe odwołanie darowizny, szczególnie wtedy, gdy przedmiot świadczenia jest podzielny, lub gdy zawarto kilka umów. W wypadku, bowiem gdy przed wykonaniem darowizny własność jej przedmiotu przeszła już na obdarowanego, to odwołanie darowizny spowoduje obowiązek powrotnego przeniesienia własności na darczyńcę, a jeżeli przedmiot został już wydany obdarowanemu, to jego zwrot będzie możliwy wedle zasad obowiązujących przy zwrocie świadczenia przy bezpodstawnym wzbogaceniu ${ }^{26}$. Na takim stanowisku stanął Sąd Najwyższy w uchwale z 7 stycznia 1967 r. Oświadczenie odwołujące darowiznę nieruchomości $\mathrm{z}$ powodu rażącej niewdzięczności nie powoduje przejścia własności nieruchomości z obdarowanego na darczyńcę, lecz stwarza jedynie obowiązek zwrotu przedmiotu odwołanej darowizny stosownie do przepisów o bezpodstawnym

\footnotetext{
${ }^{22}$ Orzeczenie Sądu Najwyższego z dnia 27 listopada 1998 r. sygn. II CKN 31/98, LexPolonica nr 37571.

${ }^{23}$ Ustawa z dnia 25 lutego 1964 r., Kodeks rodzinny i opiekuńczy, tj. Dz.U. 2012r, poz. 788, z późn. zm.

${ }^{24}$ S. Babiarz, Spadek..., s. 163.

${ }^{25} \mathrm{http}: / /$ pl.wikipedia.org/wiki/Klauzula_rebus_sic_stantibus (05.02.2014r.)

${ }^{26}$ S. Babiarz, Spadek..., s. 163.
} 
wzbogaceniu. Prawomocne orzeczenie sądu stwierdzające obowiązek strony do złożenia oznaczonego oświadczenia woli zastępuje to oświadczenie (art. 64 k.c. oraz art. 1047 k.p.c.). Jeżeli więc oświadczenie to ma stanowić składnik umowy, jaka ma być zawarta pomiędzy stronami, do zawarcia tej umowy konieczne jest złożenie odpowiedniego oświadczenia woli przez drugą stronę z zachowaniem wymaganej formy. Nie dotyczy to jednak zawarcia umowy przyrzeczonej w umowie przedwstępnej (art. 390 § 2 k.c.) oraz wypadków, gdy sąd uwzględnia powództwo o stwierdzenie obowiązku zawarcia umowy całkowicie zgodnie

z żądaniem powoda; w takich wypadkach orzeczenie sądu stwierdza zawarcie umowy i zastępuje tę umowę ${ }^{27}$.

Zważając uwagę na instytucję odwołania darowizny jeszcze niewykonanej, istotnym jest zaznaczenie, że możliwość do dokonania tej czynności przysługuje tylko i wyłącznie darczyńcy lub darczyńcom, (jeżeli dokonali darowizny wspólnie lub mogli jej tylko wspólnie dokonać, np. zobowiązać się do świadczenia, którego przedmiotem była rzecz wchodząca

w skład majątku dorobkowego małżonków). Wynika z tego, zatem że czynności odwołania darowizny jeszcze niewykonanej nie mogą uczynić ani:

- członek rodziny,

- spadkobierca ustanowiony testamentem,

- $\quad$ spadkobierca ustawowy ,

- $\quad$ osoby, wobec których ciążyły na darczyńcy określone obowiązki ${ }^{28}$.

Uprawnienie do odwołania darowizny jeszcze niewykonanej przysługuje jedynie darczyńcy, co wynika z użytego w art. 896 k.c. zwrotu, iż „,darczyńca może”, ale również ze wskazanych w tym przepisie warunków, od których spełnienia uzależniona jest możliwość skutecznego odwołania darowizny. W świetle przepisów prawa darowizna może być odwołana $\mathrm{w}$ razie pogorszenia się stanu majątkowego darczyńcy, uniemożliwiającego jej wykonanie bez uszczerbku dla jego własnego utrzymania oraz dla ciążącego na nim (a nie na innych osobach) obowiązku alimentacyjnego ${ }^{29}$. Jeśli zaś chodzi o legitymację bierną, podkreślić należy, że śmierć obdarowanego po zawarciu umowy darowizny, a przed jej wykonaniem, nie wyłącza możliwości odwołania darowizny. W takim wypadku pisemne oświadczenie o odwołaniu powinno być skierowane do spadkobierców obdarowanego. Założone w omawianym przepisie uprawnienie do odwołania darowizny darczyńca traci z chwilą jej wykonania w całości. Przez wykonanie należy przy tym rozumieć zarówno wydanie jej przedmiotów obdarowanemu, jak i zawarcie umowy rozporządzającej rzeczą (o skutkach rzeczowych) oznaczoną, co do tożsamości (np. nieruchomościa) ${ }^{30}$.

Komentatorzy art. 869 k.c. wysuwają tezę wedle, której możliwe jest odwołanie tylko części darowizny. Właściwy cel osiąga się już, bowiem wówczas, gdy darczyńca zatrzymuje taką część przedmiotu darowizny, która umożliwia mu zaspokojenie swych potrzeb oraz wywiązywanie się z ustawowych obowiązków alimentacyjnych. Nie odnosi

\footnotetext{
${ }^{27}$ Uchwała Sądu Najwyższego z dnia 7 stycznia 1967 r. sygn. III CZP 32/66, LexPolonica nr 754.

${ }^{28}$ S. Brzeszczyńska, Umowy w obrocie nieruchomościami, Wyd. C.H.Beck, Warszawa 2005, str. 556.

${ }^{29}$ S. Dmowski [w:] Komentarz ..., s. 794.

${ }^{30}$ J. Jezioro [w:] pod red. E. Gniewka, Kodeks Cywilny. Komentarz do artykutów 353- 1088, Tom 2, Wyd. C.H. Beck, Warszawa 2004, s. 656.
} 
się to jednak do przypadków, w których przedmiot darowizny nie jest podzielny ${ }^{31}$. Na uwagę zasługuje sytuacje, w której spotykamy się z częściowym odwołaniem darowizny. Według ustawodawcy działanie to może mieć dwojaki charakter, a mianowicie:

- w sytuacji, gdzie darczyńca podejmuje pewne czynności zmierzające do wydania przedmiotu darowizny,

- w sytuacji, gdy darczyńca wyda część z darowanych przedmiotów.

Pierwsza okoliczność występuje w momencie, gdy darczyńca po złożeniu oświadczenie o darowaniu określonej osobie ściśle oznaczonego przedmiotu np. samochodu to tym samym umożliwi tej osobie korzystanie swobodnie z darowanego przedmiotu. Natomiast, gdy nie wyda ściśle określonej osobie np. dokumentów koniecznych do dokonania rejestracji pojazdu to jednocześnie sam nie zaprzestanie $\mathrm{z}$ niego korzystać. W wypadku tym nie jest możliwa mowa o wykonaniu darowizny. Nie występuje, zatem sytuacja uniemożliwiająca osobie darczyńcy odwołanie darowizny na podstawie art. 896 k.c.

Druga okoliczność zaś powstaje w przypadku, gdy wydane zostaną tylko niektóre części przedmiotów z darowizny np. $5 \mathrm{z}$ darowanych 10 uli bądź niektóre z różnych przedmiotów zapisanych $\mathrm{w}$ umowie darowizny. $\mathrm{W}$ takiej sytuacji można mówić, iż niewydanie wszystkich przedmiotów z darowizny uzasadnia odwołanie jej w całości. Jednak nie jest pozbawione racji twierdzenie, ze odwołanie może odnieść skutek jedynie w odniesieniu od czesści darowizny jeszcze niewykonanej. Wobec tego darczyńca nie mógłby powołać się na odwołanie darowizny w części już wykonanej i domagać się zwrotu przedmiotów wydanych obdarowanemu ${ }^{32}$.

Jak podaje art. 896 k.c. uprawnienie do odwołania darowizny jeszcze niewykonanej uzależnione jest od zmiany stanu majątkowego darczyńcy na jego niekorzyść. Bez znaczenia dla opisanego w przepisie uprawnienia darczyńcy jest przyczyna zmiany stanu majątkowego darczyńcy. Zmiana tegoż stanu może być uzależniona od przyczyn:

- natury obiektywnej np. spadek notowań akcji będących w posiadaniu darczyńcy,

- natury subiektywnej np. nietrafione decyzje biznesowe darczyńcy,

- zmiany wywołane umyślnie,

- zmiany wywołane na skutek rażącego niedbalstwa np. podpalenie przez darczyńcę własnego przedsiębiorstwa.

Stanowisko to uzasadnia treść art. 891 § 1 k.c., z którego wynika obowiązek wynagrodzenia szkody wynikłej $\mathrm{z}$ niewykonania zobowiązania przyjętego $\mathrm{w}$ umowie darowizny ${ }^{33}$. Ważne jest zaznaczenie faktu, iż zmiana stanu majątkowego darczyńcy musi być istotna. Tylkow takiej sytuacji można mówić, że wykonanie darowizny nie może nastąpić bez uszczerbku dla utrzymania darczyńcy, odpowiednio do jego usprawiedliwionych potrzeb. Zmiany nieistotnie zaś nie mogą być podstawą odwołania darowizny, tak samo jak wykazania, iż darczyńca znajduje się w ciężkiej sytuacji materialnej.

Zdaniem komentatorów kodeksu cywilnego należy mieć na względzie charakter potrzeb, które mają być uznane za usprawiedliwione. Zwracać należy uwagę na fakt, iż

\footnotetext{
${ }^{31}$ L. Stecki, [w:] System ..., s. 353.

${ }^{32}$ S. Dmowski [w:] Komentarz...., s. 795.

33 Z. Gawlik [w:] pod red. A.Kidyby, Kodeks cywilny. Komentarz. Zobowiazania- czesść szczegótowa, Tom 2, Wyd. Lex, Warszawa 2010, s. 1189.
} 
potrzeby te mają istotę konsumpcyjną oraz że ich zaspokojenie opiera się głównie na zagwarantowaniu uprawnionemu mieszkania, wyżywienia, odzieży, leczenia itp. Pod pojęciem potrzeby usprawiedliwione należy rozumieć nie tylko minimum egzystencji człowieka, ale również jego warunki bytowania dostosowane np. do wieku, stanu zdrowia uprawionego.

Przy ocenie, w jakim stopniu zmiana stanu majątkowego darczyńcy zaistniała po zawarciu umowy darowizny wpłynęła na możliwość zaspokajania usprawiedliwionych potrzeb darczyńcy, nie można pomijać tego, na jakim poziomie zaspokajał on swoje potrzeby przed zmianą stanu majątkowego. Należy podkreślić, że ustawodawca ma w tym wypadku na względzie własne potrzeby darczyńcy, a nie potrzeby jego osób bliskich ${ }^{34}$.

\section{NIEDOSTATEK DARCZYŃCY PO WYKONANIU DAROWIZNY}

Według polskiego prawa zobowiązań nie ma mowy o odwołaniu darowizny po jej wykonaniu nawet, jeżeli darczyńca poprzez umowę darowizny popadł w niedostatek. Ustawodawca zważywszy na ochronę interesów darczyńcy a także osób, wobec których jest on ex large zobowiązujący do alimentacji aprobatę zyskało przekonanie, iż w takiej sytuacji konieczne jest obarczenie obdarowanego obowiązkiem dostarczenia darczyńcy środków, których mu brak do utrzymania odpowiadającego jego usprawiedliwionym potrzebom albo do

wypełniania ciążących na nim ustawowych obowiązków alimentacyjnych ${ }^{35}$.

W związku z tym ustawodawca wprowadził do Kodeksu Cywilnego przepis art. 897. Zgodnie z treścią tego artykułu - jeżeli po wykonaniu darowizny darczyńca popadnie w niedostatek, obdarowany ma obowiązek, w granicach istniejącego jeszcze wzbogacenia, dostarczać darczyńcy środków, których mu brak do utrzymania odpowiadającego jego usprawiedliwionym potrzebom albo do wypełnienia ciążących na nim ustawowych obowiązków alimentacyjnych. Obdarowany może jednak zwolnić się od tego obowiązku zwracając darczyńcy wartość wzbogacenia.

Z powyższego artykułu wynika, iż po stronie obdarowanego obowiązek taki powstaje, w sytuacji wystąpienia określonych przesłanek, a mianowicie:

- między obdarowanym a darczyńcą musi zaistnieć więź o charakterze obligacyjnym, jaką kreuje czynność zawarcia umowy darowizny,

- darczyńca musi wykonać darowiznę, co wyklucza powstanie takiego obowiązku w przypadku darowizny, która wykonana jeszcze nie została,

- $\quad$ występowanie niedostatku darczyńcy lub zaktualizowanie się ustawowej powinności alimentacyjnej darczyńcy wobec osób trzecich.

Ustawodawca nie określił, co należy rozumieć przez pojęciem „niedostatek”. Dlatego też w każdym konkretnym przypadku to właśnie sąd będzie decydował, co uznać za niedostatek.

W doktrynie przyjmuje się, że niedostatek, o którym mowa powyżej dotyczy dwóch sytuacji, a mianowicie:

- braku środków potrzebnych darczyńcy do zaspokojenia jego usprawiedliwionych potrzeb,

\footnotetext{
${ }^{34}$ S. Dmowski [w:] Komentarz..., s. 797.

${ }^{35}$ L. Stecki [w:] System..., s. 356.
} 
- braku środków potrzebnych darczyńcy do wypełnienia ciążących na nim ustawowych obowiązków alimentacyjnych ${ }^{36}$.

Przepisy prawa nie definiują niedostatku i odnośnie tego, czym jest niedostatek należy sięgnąc do orzecznictwa sądów i doktryny prawa.

Sąd Najwyższy stanął na stanowisku, iż w niedostatku znajduje się ten, kto nie może własnymi siłami zaspokoić swoich usprawiedliwionych potrzeb (to takie, których zaspokojenie zapewni uprawnionemu normalne warunki bytowania, odpowiednie do jego stanu zdrowia i wieku) w całości lub w części. Stan niedostatku, według Sądu, to na pewno nie jest taka sytuacja, w której osoba nie ma po prostu żadnego dochodu i majątku ${ }^{37}$.

Kolejnej interpretacji niedostatku Sąd Najwyższy daje wyraz w wyroku z dnia 20 stycznia $2000 \mathrm{r}$. W tym orzecznictwie znajdujemy informację, iż w niedostatku pozostaje nie tylko taki uprawniony, który nie dysponuje żadnymi środkami utrzymania, ale także taki, którego usprawiedliwione potrzeby są w pełni zaspokojone ${ }^{38}$.

Zarówno powstanie jak i samo istnienie obowiązku obdarowanego jest uzależnione od tego czy obdarowany jest jeszcze wzbogacony. Wielkość istniejącego wzbogacenia jest ustalana według stanu $\mathrm{z}$ daty, w której obdarowany dowiedział się o niedostatku darczyńcy, a nie dopiero od momentu zgłoszenia stosownego żądania przez darczyńcę. Należy, bowiem przyjąć, że od tego momentu obdarowany powinien był się liczyć z obowiązkiem świadczenia na rzecz darczyńcy. Przyjęcie innego stanowiska praktycznie paraliżowałoby roszczenie darczyńcy ${ }^{39}$.

Art. 897 k.c. ma na uwadze jedynie niedostatek, który wystąpił po wykonaniu darowizny, przy czym przyczyna powstania takiego stanu rzeczy nie jest obojętna. Jeżeli natomiast niedostatek zostanie wywołany umyślnie lub w skutek rażącego niedbalstwa przez darczyńcę wówczas nie usprawiedliwi to przywileju darczyńcy do świadczeń przewidzianych w art. 897 k.c. Wypada tutaj zaznaczyć, iż ocenę takiego postępowania należy przeprowadzać z uwzględnieniem zasad współżycia społecznego. Prowadzi to tym samym, do stwierdzenia, iż zachowanie to nie może być przejawem nadużycia prawa podmiotowego jak podaje art. 5 k.c. A więc nie można czynić ze swego prawa użytku, który by był sprzeczny ze społeczno-gospodarczym przeznaczeniem tego prawa lub z zasadami współżycia społecznego. Takie działanie lub zaniechanie uprawnionego nie jest uważane za wykonywanie prawa i nie korzysta $\mathrm{z}$ ochrony ${ }^{40}$.

Art. 897 k.c. jasno pokazuje, iż powinności wykonywane w jego ramach mają niewątpliwie charakter świadczeń alimentacyjnych. Obowiązek płacenia tych świadczeń wygasa w chwili, gdy następuje śmierć darczyńcy. Obowiązek ten wygasa także w momencie wyczerpania się wartości przedmiotu darowizny, według stanu z chwili powstania obowiązku świadczenia, chociażby darczyńca znajdował się nadal w niedostatku. Art. 897 k.c. zwalnia z obowiązku płacenia świadczeń alimentacyjnych w

\footnotetext{
${ }^{36}$ J. Jezioro [w:] Kodeks..., s. 1438

${ }^{37}$ Wyrok Sądu Najwyższego z dnia 7 września 2000r., sygn. akt. I CKN 872/2000, LexPolonica nr 2210519.

${ }^{38}$ Wyrok Sądu Najwyższego z dani 20 stycznia 2000r., sygn. akt. I CKN 1187/99, LexPolonica nr 379749.

${ }^{39}$ M. Safjan [w:] pod red. K. Pietrzykowskiego, Kodeks Cywilny. Komentarz do artykułów 4501088, Tom 2, Wyd. C.H.Beck, Warszawa 2011,s. 890.

${ }^{40}$ S. Dmowski [w:] Komentarz..., s. 800.
} 
sytuacji, gdy obdarowany zwróci darczyńcy wartość wzbogacenia. Jednak nie może to być przedmiot darowizny, jak to następuje w wypadku uregulowanym w art. $895 \S 2)^{41}$.

Bardzo istotne $\mathrm{w}$ omawianym zakresie, jest fakt, aby stan niedostatku powstał po wykonaniu darowizny. Jeżeli taki stan nastąpi wcześniej, to reguła wynikająca z treści art. 897 k.c. nie znajdzie zastosowania. W takim przypadku darczyńca musi zastosować się do przepisu zawartego w art. 896 k.c., który brzmi: „darczyńca może odwołać darowiznę jeszcze nie wykonaną, jeżeli po zawarciu umowy jego stan majątkowy uległ takiej zmianie, że wykonanie darowizny nie może nastapić bez uszczerbku dla jego własnego utrzymania odpowiednio do jego usprawiedliwionych potrzeb albo bez uszczerbku dla ciążących na nim ustawowych obowiązków alimentacyjnych.” Poza powyżej uwidocznionym stanem niedostatku, a ściślej mówiąc jego wielkości, zakres obowiązku z art. 897 k.c. kształtuje jeszcze jeden aspekt. Jest nim oczywiście wielkość istniejącego wzbogacenia obdarowanego (ocenia powinna nastąpić według przepisów Tytułu V, Księgi trzeciej, Kodeksu cywilnego - art. 405 - 414 k.c.). Legislator, ustalając dyspozycję do art. 897 k.c., mówi, iż obdarowany może zwolnić się z obciążenia dostarczania darczyńcy środków. Stworzył tym samym dla obdarowanego tzw. upoważnienie przemienne (facultas alternativa), które ma na celu zapewnienie mu prawa do wyboru świadczenia. Według facultas alternativa obdarowany na prawo wyboru, czy:

- będzie doprowadzał do realizacji świadczenia okresowe na poczet darczyńcy,

- zwróci wartość wzbogacenia.

Zwrot wartości wzbogacenia, o którym mowa powyżej, może występować w dwóch formach, a mianowicie:

- zwrot przedmiotu darowizny w takim stanie, jaki istniał w momencie powstania obowiązku zwrotu,

- $\quad$ wypłacenie całej wartości darowizny w postaci pieniężnej ${ }^{42}$.

Przy sprecyzowaniu wartości wzbogacenia, należy zastosować do obliczeń reguły wynikające z art. 406 k.c. oraz art. 409 k.c. Pierwszy z nich mówi o tym, iż „obowiązek wydania korzyści obejmuje nie tylko korzyść bezpośrednio uzyskaną, lecz także wszystko, co w razie zbycia, utraty lub uszkodzenia zostało uzyskane w zamian tej korzyści albo, jako naprawienie szkody". Natomiast drugi, opowiada się za tym, iż „obowiązek wydania korzyści lub zwrotu jej wartości wygasa, jeżeli ten, kto korzyść uzyskał, zużył ją lub utracił w taki sposób, że nie jest już wzbogacony chyba, że wyzbywając się korzyści lub zużywając ją powinien był liczyć się z obowiązkiem zwrotu".

Jak podaje ustawodawca, pomiędzy odwołaniem darowizny a zwrotem wzbogacenia występuje fundamentalna odmienność. Zwrot wzbogacenia stanowi realizację uprawnienia przemiennego obdarowanego oraz zwrot nie oznacza upadku darowizny. Natomiast odwołanie darowizny dochodzi do skutku w wyniku czynności samego darczyńcy ${ }^{43}$.

\footnotetext{
${ }^{41}$ Ibidem, s.801.

${ }^{42}$ M. Safjan [w:] Kodeks..., s. 890.

${ }^{43}$ M. Safjan [w:] Kodeks..., s. 891.
} 


\section{ODWOŁANIE DAROWIZNY WYKONANEJ}

Zgodnie z treścią art. 897 k.c. - jeżeli po wykonaniu darowizny darczyńca popadnie w niedostatek, obdarowany ma obowiązek, w granicach istniejącego jeszcze wzbogacenia, dostarczać darczyńcy środków, których mu brak do utrzymania odpowiadającego jego usprawiedliwionym potrzebom albo do wypełnienia ciążących na nim ustawowych obowiązków alimentacyjnych. Obdarowany może jednak zwolnić się od tego obowiązku zwracając darczyńcy wartość wzbogacenia. Obowiązek obdarowanego, o którym tu mowa, jest przejawem istnienia więzi pozajurydycznej między stronami, obowiązującej obdarowanego do wdzięczności za otrzymaną szczodrobliwość ${ }^{44}$. Natomiast, jeżeli chodzi o pojęcie niedostatku darczyńcy należy przez nie rozumieć taki stan, który wprawdzie nie wiąże się z zupełnym niezaspokojeniem usprawiedliwionych potrzeb, ale zachodzi już wtedy, gdy uprawniony nie może zaspokoić swoich usprawiedliwionych potrzeb przy uwzględnieniu swoich możliwości zarobkowych i majątkowych ${ }^{45}$.

Ochrona przed następstwami darowizny jest uzasadniona tylko w sytuacjach, gdy stan majątkowy darczyńcy uległ zmianie już po zawarciu umowy darowizny. Zatem uprawnienie do odwołania darowizny jeszcze niewykonanej zawiera w sobie czas miedzy zawarciem umowy a jej wykonaniem. Wykonanie umowy darowizny pozbawia darczyńcę prawa odwołania darowizny na podstawie omawianego przepisu. Zawarcie umowy darowizny $\mathrm{i}$ jej skutek $\mathrm{w}$ postaci zubożenia darczyńcy oraz jego najbliższych nie uzasadnia potrzeby jego ochrony. Zmniejszenie dobrobytu darczyńcy, przy braku jakichkolwiek po jego stronie korzyści, jest, bowiem istotą umowy darowizny. Mogą jednak zdarzyć się sytuacje, gdy osoby, które dokonały darowizny, pragną ją odwołać, bowiem zmusza ich do tego niespodziewane pogorszenie się ich sytuacji majątkowej ${ }^{46}$.

W orzecznictwie, Sąd Najwyższy zajął stanowisko w wyroku z 27 listopada 1998 r. Środki uzyskiwane sporadycznie lub wyłącznie ze współczucia nie wpływają na ocenę istnienia niedostatku w rozumieniu art. 897 k.c. ${ }^{47}$. Granicę żądań, o których wyżej mowa, formułują usprawiedliwione potrzeby darczyńcy oraz ciążące na nim prawne zobowiązania alimentacyjne. Zasadniczo, rozmiar poruszanych żądań nie jest związany wprost

z przedmiotem darowizny. Miarą uprawnienia darczyńcy, przewidzianego komentowanym przepisem, są m.in.:

- istniejące jeszcze wzbogacenie obdarowanego powstałe na skutek dokonania darowizny,

- rozmiar braków w środkach potrzebnych do usprawiedliwionego utrzymania obdarowanego,

- ciążące na obdarowanym prawne obowiązi alimentacyjne ${ }^{48}$.

\footnotetext{
${ }^{44}$ W. Czachórski, Zobowiqzania..., s. 553.

${ }^{45}$ S. Babiarz, Spadek..., s.164.

${ }^{46}$ Z. Gawlik, A. Janiak, A. Kidyba, K. Kopaczyńska-Pieczniak, G. Kozieł, E. Niezbecka, T. Sokołowski, Kodeks cywilny. Komentarz. Tom III. Zobowiązania - część szczególna, Wyd. Lex, Warszawa 2010, s. 688.

47 Wyrok Sądu Najwyższego z dnia 27 listopada 1998 r. sygn. III CKN 31/98, LexPolonica nr 219257.

${ }^{48}$ Z. Gawlik, A. Janiak, A. Kidyba, K. Kopaczyńska-Pieczniak, G. Kozieł, E. Niezbecka, T. Sokołowski, Kodeks..., s.690.
} 
Przy ocenie obowiązków obdarowanego wobec darczyńcy, wynikających ze stosunków osobistych (rodzinnych), jak i etycznego obowiązku wdzięczności, sąd może posiłkować się treścią art. 897 k.c. Przepis ten, jako mający na celu zabezpieczenie interesów darczyńcy w wypadku popadnięcia w niedostatek, stanowi, że obowiązek obdarowanego kształtowany jest nie tylko przez potrzebę darczyńcy, ale i przez granice wzbogacenia ${ }^{49}$.

Praktycznym przejawem roszczenia powoda darczyńcy w ramach uprawnienia wynikającego z art. 897 k.c. będzie złożenie przez niego powództwa o rentę. Możliwy jest także zbieg podstaw do zasądzenia renty i świadczeń alimentacyjnych, nawet w stosunku do tej samej osoby. W związku z przysługującym obdarowanemu uprawnieniem do zwrotu wartości wzbogacenia $\mathrm{w}$ naturze, należy podnieść, że skorzystanie $\mathrm{z}$ niego nie może być utożsamiane $\mathrm{z}$ sytuacją prawną, w jakiej znalazłby się obdarowany na skutek odwołania darowizny, gdyż - pomijając to, że przysługują one różnym stronom - zwrot przedmiotów darowizny w zakresie wartości wzbogacenia nie oznacza bezpodstawności dotychczasowego wzbogacenia, z którego obdarowany już skorzysta ${ }^{50}$.

Prawo do odwołania darowizny już wykonanej posiada tylko darczyńca w świetle art. $898 \S 1$ k.c. Wedle przytaczanego artykułu czynności tej nie może wykonywać żadna inna osoba trzecia. Ma to związek również w sytuacji, w której obdarowany dopuszcza się karygodnych czynów wobec osoby bliskiej darczyńcy, naciskając na darczyńcę tylko w sposób pośredni. Osoba taka również nie może dokonać czynności odwołania darowizny.

Prawo od odwołania darowizny wykonanej przechodzi na spadkobierców darczyńcy po jego śmierci. Zgodnie z treścią art. 898 § 2 k.c. spadkobiercy darczyńcy mogą odwołać darowizna z powodu rażącej niewdzięczności w trzech sytuacjach takich jak:

- gdy darczyńca w chwili śmierci był uprawniony od odwołania darowizny,

- gdy obdarowany umyślnie pozbawił darczyńcę życia,

- gdy obdarowany umyślnie wywołał rozstrój zdrowia, którego skutkiem była śmierć darczyńcy.

Powyższe postępowanie dotyczy sytuacja, w której odwołanie darowizny nie nastąiło za życia darczyńcy. Norma ta nie ma natomiast zastosowania w sytuacji, gdy darczyńca odwołał darowiznę i zmarł po jej wykonaniu ${ }^{51}$.

\section{RAŻĄCA NIEWDZIĘCZNOŚĆ OBDAROWANEGO}

Zgodnie z treścią art. 898 § 1 k.c. „,darczyńca może odwołać darowiznę nawet już wykonaną, jeżeli obdarowany dopuścił się względem niego rażącej niewdzięczności” natomiast art. 898 \& 2 k.c. mówi, iż ,zwrot przedmiotu odwołanej darowizny powinien nastąić stosownie do przepisów o bezpodstawnym wzbogaceniu. Od chwili zdarzenia uzasadniającego odwołanie obdarowany ponosi odpowiedzialność na równi $z$ bezpodstawnie wzbogaconym, który powinien się liczyć z obowiązkiem zwrotu."

Przepis ten należy do grupy, zawierających $\mathrm{w}$ swej treści zwroty niedookreślone. Zwroty niedookreślone używane są przez ustawodawcę, kiedy ten świadomie zmierza do pozostawienia organom stosującym prawo pewien margines luzu cennego ze względu na

\footnotetext{
${ }^{49}$ Wyrok Sądu Najwyższego z dnia 7 maja 2003 r. sygn. IV CKN 115/01, LexPolonica nr 137593.

${ }^{50}$ S. Babiarz, Spadek..., s. 165.

${ }^{51}$ Postanowienie Sądu Apelacyjnego w Lublinie z dnia 2 grudnia 1997r., sygn. I ACz 478/97, LexPolonica nr 2129042.
} 
konieczność uniknięcia mało elastycznych, kazuistycznych unormowań ${ }^{52}$. Darowizna w tym wypadku generuje pewien rodzaj stosunku etycznego między darczyńcą i obdarowanym. Stosunek ten wyraża się w moralnym obowiązku wdzięczności. Nie można doprowadzić do sytuacji, w której obdarowany jest niewdzięczny względem swojego darczyńcy. Według ustawodawcy nikt niegodny nie może korzystać z pracy jak i z majątku darczyńcy. Leży tow interesie społecznym, aby do takiej sytuacji nie dopuścić. Brak ekwiwalentu w omawianym typie umowy ma charakter czysto formalny, gdyż darowizna nakłada na obdarowanego więzy zobowiązujące go do szczególnego zachowania względem darczyńcy, dając mu możliwość podjęcia określonych czynności w razie naruszenia tego obowiązku ${ }^{53}$. Taką interpretację tego przepisu podziela Sąd Najwyższy wskazując, jako przesłankę uprawnienia darczyńcy do odwołania darowizny ustawodawca w art. 898 k.c. statuuje rażącą niewdzięczność. Posługuje się, więc typowym zwrotem niedookreślonym, pozostawiając sądowi ustalenie, czy konkretne zachowania mieszczą się w pojęciu rażącej niewdzięczności i odsyłając w tym zakresie przede wszystkim do układu norm moralnych. Dobre obyczaje w konkretnym środowisku i zwyczajowe relacje między obdarowanym a darczyńcą mogą stanowić jedno z pomocnych w ocenie zachowania obdarowanego kryteriów. Wprawdzie do esentialia negotii umowy darowizny nie należy obowiązek sprawowania opieki nad darczyńcą przez obdarowanego, to jednak umowa darowizny rodzi po stronie obdarowanego moralny obowiązek wdzięczności, który nabiera szczególnej wymowy, gdy do zawarcia umowy dochodzi między osobami najbliższymi, których powinność świadczenia pomocy i opieki wynika już z łączących strony umowy stosunków rodzinnych ${ }^{54}$.

Naruszenie tego obowiązku w sposób dotkliwy dla darczyńcy powoduje konsekwencję przewidzianą w art. $899 \S 1$ k.c. Polega ona przede wszystkim na powstaniu uprawnienia darczyńcy od odwołania darowizny. Analogicznie do treści przepisu 899 §1 k.c. darczyńca może odwołać darowiznę już wykonaną, jeżeli obdarowany podpuścił się względem niego rażącej niewdzięczności. Kluczowe jest tutaj podkreślenie, iż odwołanie darowizny z powodu rażącej niewdzięczności obdarowanego może dotyczyć zarówno darowizny już wykonanej, jak i umowy zobowiązującej, ale jeszcze niewykonanej. Jedyną przesłanką dopuszczalności odwołania darowizny jest w tym wypadku wspomniana już rażąca niewdzięczność, która musi wystapić po zawarciu umowy darowizny. Gdy zdarzenie uzasadniające przyjęcie rażącej niewdzięczności miało miejsce przed zawarciem umowy darowizny, a darczyńca dowiedział się o nim dopiero po jej zawarciu, nie mógłby odwołać darowizny w trybie przewidzianym w art. 898 k.c. W takim przypadku mogłoby wchodzić w grę jedynie uchylenie się darczyńcy od skutków oświadczenia woli złożonego w umowie darowizny ${ }^{55}$.

W orzecznictwie Sądu Najwyższego przyjmuje się, iż pojęcie rażącej niewdzięczności to tylko takie działania oraz zachowania obdarowanego, które są wystosowane tylko i wyłącznie w darczyńce z zamiarem nieprzyjemnym. Według orzecznictwa chodzi tu przede wszystkim o dopuszczenie się przestępstwa przeciwko darczyńcy (przeciwko życiu, zdrowiu, mieniu oraz czci) oraz naruszenie przez obdarowanego obowiązków

\footnotetext{
${ }^{52}$ T. Filipiak, J. Mojak, M. Nazar, E. Niezbecka, Zarys..., s. 64.

${ }^{53}$ A. Ohanowicz, J. Górski, Zarys prawa zobowiazań, Wyd. PWN, Warszawa 1970, s. 500.

${ }^{54}$ Wyrok Sądu Najwyższego z dnia 13 października 2005r. sygn. I CK 112/05, LexPolonica nr 186998.

${ }^{55}$ S. Dmowski [w:] Komentarz..., s. 802.
} 
wynikających ze stosunków osobistych łączących go z osoba darczyńcy np. odmowa udzielenia pomocy w czasie choroby mimo oczywistej możliwości. Zarówno czyny nieumyślne spowodowane przez obdarowanego jak i czyny częściowo umyślne, ale niewykraczające poza ramy zwykłych konfliktów życiowych (rodzinnych) nie wyczerpują znamion rażącej niewdzięczności.Z działań rażącej niewdzięczności wyłączone zostały także krzywdy wyrządzone darczyńcy w sposób niezamierzony przez czyny popełnione w uniesieniu lub rozdrażnieniu, spowodowane zachowaniem się lub działaniem darczyńcy. Według Sądu Najwyższego o tym czy mamy do czynienia z rażącą niewdzięcznością należy decydować tylko po uwzględnieniu wszystkich okoliczności dotyczących obdarowanego jak i darczyńcy ${ }^{56}$.

Odwołanie darowizny $\mathrm{z}$ powodu niewdzięczności musi być bardzo mocno uzasadnione. Jest to czynność nadzwyczajna. Ustawodawca wyróżnia kilka przesłanek rażącej niewdzięczności, do których zaliczamy:

- czyn lub zaniechanie będący przejawem rażącej niewdzięczności musi być wymierzony bezpośrednio, lub pośrednio w darczyńcę,

- zarówno działanie, jak i zaniechanie musi być rażącym naruszeniem norm społecznych i rodzinnych.

Do rażącej niewdzięczności ustawodawca zalicza takie zachowania jak:

- przemoc fizyczna,

- znęcanie się,

- nieudzielenie pomocy mino oczywistych możliwości,

- nie wypełnienie obowiązku alimentacyjnego mino oczywistych możliwości,

- zaniedbanie w przypadku osoby nieporadnej ( np. schorowanej),

- przemoc psychiczna,

- poważne pomówienie np. złożenie fałszywego zawiadomienia o podejrzeniu popełnienia przestępstwa, pomówienie publiczne, lżenie,

- oszustwo,

- $\operatorname{kradzież}^{57}$.

Sąd Najwyższy podejmuje również działania legislacyjne wykluczające pewne zachowania z przedmiotu darowizny. Wyrokiem z 23 marca 2000 r. wyklucza spośród klauzuli rażącej niewdzięczności między innymi:

- nieudzielanie darczyńcy pomocy w pracach rolnych i w opiece nad upośledzonym dzieckiem (II CKN 810/98),

- zawiedzione oczekiwania darczyńcy, co do należytego zajmowania się przez obdarowanego przedmiotem darowizny (II CK 265/05),

- nieuzgodnione $\mathrm{z}$ darczyńcą akty wykonywania uprawnień właścicielskich wobec przedmiotu darowizny (II CK 63/04),

- zewnętrzne objawy zachowania się obdarowanego nieuwzględniające jego motywów i intencji (II CKN 218/98) ${ }^{58}$.

\footnotetext{
${ }^{56}$ Wyrok Sądu Najwyższego z dnia 4 lutego 2005 r. sygn. I CK 571/2004, LexPolonica nr 2794844. http://www.infor.pl/prawo/darowizny/wykonanie-i-odwolanie-darowizny/79922,Kiedy-moznaodwolac-wykonana-darowizne.html (05.02.2014r.)

${ }^{58}$ Wyrok Sądu Najwyższego z dnia 13 października 2005r. sygn. I CK 112/05, LexPolonica nr 186998.
} 
Orzecznictwem Sądu Najwyższego można stwierdzić, iż ustalenie rażącej niewdzięczności po stronie obdarowanego wymaga poznania wszystkich jego zachowań względem darczyńcy np. czy zachowania te były powodowane czy wręcz prowokowane przez darczyńcę. W orzecznictwie tym pokazano, iż incydentalne sprzeczki po między obdarowanym a darczyńca nie mogę być powodem odwołania darowizny ${ }^{59}$.

\section{PRZEBACZENIE OBDAROWANEMU}

Na zakończenie warto wspomnieć, że zgodnie z literą prawa darowizna nie może być odwołana z powodu niewdzięczności, jeżeli darczyńca obdarowanemu przebaczył. Mówi o tym art. 899 § 1 k.c. Według ustawodawcy za istotę przebaczenia należy przyjąć fikcję zawarcia w pamięci przebaczającego zachowania, które kwalifikowane jest, jako przejaw niewdzięczności. Przebaczenie dokonane przez darczyńcę likwiduje, zatem konsekwencje rażącej niewdzięczności obdarowanego. Tym samym, pomiędzy stronami tego stosunku prawnego dochodzi do przywrócenia takiego stanu rzeczy, jaki istniał przed popełnieniem przebaczenia. Dlatego też działanie to powoduje całkowite wyłączenie uprawnienia do odwołania darowizny ${ }^{60}$.

W myśl art. 60 k.c. przebaczenie nie jest oświadczeniem woli. W konsekwencji należy stwierdzić, iż jest to tylko przejaw zbliżony do oświadczenia woli i jest traktowany przez ustawodawcę, jako rodzaj czynności prawnej. Dlatego też przebaczenia może dokonać każda osoba, która nie posiada zdolności do czynności prawnej jak również osoba całkowicie ubezwłasnowolniona. Jeżeli w chwili przebaczenia darczyńca nie miał zdolności do czynności prawnych, przebaczenie jest skuteczne, gdy nastąpiło $\mathrm{z}$ dostatecznym rozeznaniem.

Przebaczenie jest czynnością czysto osobistą i nie może być dokonywana przez kogokolwiek innego niż sam darczyńca. Darczyńca, zatem nie ma prawa upoważnić żadnej innej osoby do dokonania przebaczenia w jego imieniu. Nawet gdyby posiadał pełną zdolności do czynności prawnych oraz działaby z pełnym rozeznaniem to prawo stanowczo zabrania przekazywania czynności przebaczenia osobom trzecim. Ustawodawca zaś, co do formy, w jakiej ma być udzielana czynność przebaczenia nie wprowadza żadnych rygorów. Może to być, zatem każde zachowanie darczyńcy, której jest wyrażone W sposób zrozumiały dla otoczenia. Podobnie jak w przypadku oświadczenia woli, może wchodzić tu w grę przebaczenie dokonane w drodze czynności konkludentnych np. przywrócenie przez darczyńcę takich samych relacji z obdarowanym, jakie istniały przed wystąpieniem rażącej niewdzięczności. Biorąc pod uwagę charakter przebaczenia dopuszczalna zdaje się być ostrożna analogia do przepisów odnoszących się do wad oświadczenia woli. Ze swej natury przebaczenie nie jest skuteczne, gdy po stronie darczyńcy wystąpił brak świadomości lub swobody. Jeżeli w zachowaniu darczyńcy wystąpiły takie wady oświadczeń woli jak: błąd, podstęp oraz groźba to przebaczenie również nie wywoła żadnych skutków prawnych. Wyżej wymienione wady oświadczeń woli uniemożliwiają, bowiem uznanie, że darczyńca kierował się rzeczywista intencją przebaczenia. Charakter przebaczenia, zatem pokazuje, iż wystarczy powiązanie między mylnym wyobrażeniem darczyńcy o istniejącym stanie rzeczy a zamiarem przebaczenia ${ }^{61}$.

\footnotetext{
${ }^{59}$ Wyrok Sądu Najwyższego z dnia 30 września 1997 r., sygn.. III CKN 170/ 97, LexPolonica nr 50614.

${ }^{60}$ J. Jezioro [w:] Kodeks..., s. 666.

${ }^{61}$ M. Safjan [w:] Kodeks..., s. 903.
} 
Uprawnienia dotyczące czynności przebaczenia nie są objęte dziedziczeniem. Prawo do dokonania przebaczenia posiada tylko i wyłącznie darczyńca. Istotnym jest fakt, iż może ono być dokonane po akcie niewdzięczności, ale przed odwołaniem darowizny.

Oceny, czy przebaczenie zostało dokonane $\mathrm{z}$ dostatecznym rozeznaniem, należy dokonywać w odniesieniu do czasu, w którym jest ono dokonywane. Przebaczenie jest uznawane za ,jeden z najpiękniejszych czynów o charakterze moralnym”, który jak gdyby

„zniewala ustawodawcę od uwolnienia od ujemnych skutków osobę”, przeciwko której zwraca się sankcja cywilna właśnie ze względów moralnych ${ }^{62}$.

\section{LITERATURA}

[1] Babiarz S., Spadek $i$ darowizna $w$ prawie cywilnym $i$ podatkowym, Wyd. LexisNexis, Warszawa 2008.

[2] Brzeszczyńska S., Umowy w obrocie nieruchomościami, Wyd. C.H.Beck, Warszawa 2005

[3] Czachórski W. , Zobowiazania. Zarys Wykładu, Wyd. LexisNexis, Warszawa 2009.

[4] Dębiński A., Rzymskie prawo prywatne. Kompendium, Wyd. LexisNexis, Warszawa 2007.

[5] Dmowski S. [w:] pod red. Bieniek G., Komentarz do kodeksu cywilnego. Księa Trzecia. Zobowiazania, Tom 2, Wyd. LexisNexis, Warszawa 2007.

[6] Filipiak T., Mojak J., Nazar M., Niezbecka E., Zarys prawa cywilnego, Wyd. Verba, Lublin 2003

[7] Gawlik Z. [w:] pod red. Kidyby A., Kodeks cywilny. Komentarz. Zobowiazaniaczęść szczegótowa, Tom 2, Wyd. Lex, Warszawa 2010.

[8] Gawlik Z., Janiak A., Kidyba A., Kopaczyńska-Pieczniak K., Kozieł G., Niezbecka E., Sokołowski T., Kodeks cywilny. Komentarz. Tom III. Zobowiazania - część szczególna, Wyd. Lex, Warszawa 2010.

[9] http://pl.wikipedia.org/wiki/Klauzula_rebus_sic_stantibus

[10]http://www.infor.pl/prawo/darowizny/wykonanie-i-odwolaniedarowizny/79922,Kiedy-mozna-odwolac-wykonana-darowizne.html (05.02.2014r.)

[11]Jezioro J. [w:] pod red. Gniewka E., Kodeks Cywilny. Komentarz do artykułów 353- 1088, Tom 2, Wyd. C.H. Beck, Warszawa 2004.

[12]Kuryłowicz M., Wiliński A., Rzymskie prawo prywatne. Zarys wykładu, wyd. Wolters Kluwers Business, Warszawa 2008.

[13] Ohanowicz A., Górski J., Zarys prawa zobowiazań, Wyd. PWN, Warszawa 1970.

[14] Orzeczenie Sądu Najwyższego z dnia 26 czerwca 2001 r., sygn. I CA 1/01, LexPolonica $\mathrm{nr} 49117$.

[15] Orzeczenie Sądu Najwyższego z dnia 27 listopada 1998 r. sygn. II CKN 31/98, LexPolonica nr 37571.

\footnotetext{
${ }^{62}$ Z. Gawlik, A. Janiak, A. Kidyba, K. Kopaczyńska-Pieczniak, G. Kozieł, E. Niezbecka, T.
} Sokołowski, Kodeks..., s. 695. 
[16]Postanowienie Sądu Apelacyjnego w Lublinie z dnia 2 grudnia 1997r., sygn. I ACz 478/97, LexPolonica nr 2129042.

[17]Radwański Z. , Olejniczak A., Zobowiazania - część ogólna, Wyd. C.H. Beck, Warszawa 2006.

[18]Safjan M. [w:] pod red. Pietrzykowskiego K. , Kodeks Cywilny. Komentarz do artykułów 450- 1088, Tom 2, Wyd. C.H.Beck, Warszawa 2011.

[19] Stecki L. [w:] pod red. Rajski J., System prawa prywatnego. Prawo zobowiazańczęść szczegótowa, Tom 7, Wyd. C.H. Beck, Warszawa 2011.

[20]Uchwała Sądu Najwyższego z dnia 24 czerwca 2004 r. sygn. III CZP 30/04, LexPolonica nr 108156.

[21]Uchwała Sądu Najwyższego z dnia 7 stycznia 1967 r. sygn. III CZP 32/66, LexPolonica $\mathrm{nr} 754$.

[22]Ustawa z dnia 23 kwietnia 1964r. Kodeks cywilny, tj. Dz.U. 1964, Nr 16, poz. 93 z póź. $z m$.

[23]Ustawa z dnia 25 lutego 1964 r., Kodeks rodzinny i opiekuńczy, tj. Dz.U. 2012r, poz. 788 , z późn. zm.

[24]Warciński M., Odwołanie darowizny wykonanej, Instytut Wymiaru Sprawiedliwości, Warszawa 2012.

[25]Wyrok Sądu Najwyższego z dani 20 stycznia 2000r., sygn. akt. I CKN 1187/99, LexPolonica nr 379749.

[26]Wyrok Sądu Najwyższego z dnia 13 października 2005r. sygn. I CK 112/05, LexPolonica nr 186998.

[27]Wyrok Sądu Najwyższego z dnia 13 października 2005r. sygn. I CK 112/05, LexPolonica nr 186998.

[28]Wyrok Sądu Najwyższego z dnia 27 listopada 1998 r. sygn. III CKN 31/98, LexPolonica nr 219257.

[29]Wyrok Sądu Najwyższego z dnia 30 września 1997 r., sygn.. III CKN 170/ 97, LexPolonica nr 50614.

[30]Wyrok Sądu Najwyższego z dnia 4 lutego 2005 r. sygn. I CK 571/2004, LexPolonica nr 2794844.

[31]Wyrok Sądu Najwyższego z dnia 7 maja 2003 r. sygn. IV CKN 115/01, LexPolonica nr 137593.

[32]Wyrok Sądu Najwyższego z dnia 7 września 2000r., sygn. akt. I CKN 872/2000, LexPolonica nr 2210519.

\section{LEGAL NATURE OF THE CONTRACT OF DONATION - SOME PROBLEMS}

The issue of donation appeal is a complex matter and not always has a chance to succeed. Donation can indeed appeal, but only because of the blatant ingratitude of the donee to the donor and the donor's financial status has deteriorated in such a way that the execution of donation cannot take place without prejudice to its own maintenance, according to the justified needs or without prejudice to honor its statutory maintenance obligations. Thus, a necessary prerequisite to an effective remedy donation is blatant ingratitude or deterioration of the financial situation of the donor.

The Civil Code, however, does not explain what a "blatant ingratitude" is. The answers must be sought in the case law of the Supreme Court, according to which "ingratitude" in particular is such the behaviors of the recipient, which are directed against the donor of hostile intent. This is primarily an offense against the donor, for example, against health, life, honor, property and the violation by the recipient obligations arising from personal 
relationships linking it with donor - such as the refusal to provide assistance in case of illness. They are treated as minor acts of blatant ingratitude - even intentional - but do not go beyond the usual family conflicts.

It is important to note that not every donor's worsening financial situation justifies an appeal when the donation has not been made yet, because this deterioration must be important. Changes irrelevant does not give grounds for appeal donations. Finally, it should be noted that despite the unworthy behavior of the recipient donations cannot be dismissed, if the donor forgave the donator. Forgiveness can be in any form, both oral and written.

Keywords: donation, appeal donation, blatant ingratitude.

DOI:10.7862/rz.2014.hss.55

Przesłano do redakcji: luty 2014

Przyjęto do druku: grudzień 2014 